\title{
Relationship of ALDH2 rs671 and CYP2E1 rs2031920 with hepatocellular carcinoma susceptibility in East Asians: a meta-analysis
}

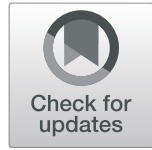

\author{
Junhong Chen ${ }^{1}$, Weicong Pan², Yongjin Chen², Lijia Wen², Jihao Tu and Kai Liu² ${ }^{2 *}$
}

\begin{abstract}
Background: Aldehyde dehydrogenase 2 (ALDH2) and cytochrome p450 2E1 (CYP2E1) are important alcoholmetabolizing enzymes. The aim of this meta-analysis was to evaluate the association of ALDH2 rs671 and CYP2E1 rs2031920 polymorphisms with hepatocellular carcinoma (HCC) susceptibility in East Asians.

Methods: A systematic search strategy was implemented in MEDLINE, PubMed, Scopus, Embase, and China Academic Journals databases. Nineteen case-control studies were selected for inclusion. Pooled odds ratios (ORs) and $95 \%$ confidence intervals (Cls) were calculated through random-effects or fixed-effects models. Subgroup analysis, meta-regression, sensitivity analysis, cumulative meta-analysis, and evaluation of publication bias were performed.

Results: The overall meta-analysis did not find a significant association of ALDH2 rs671 and CYP2E1 rs2031920 genotypes with HCC susceptibility in East Asians. In addition, stratified analysis by country, Hardy-Weinberg equilibrium status, and source of controls also did not identify any association.
\end{abstract}

Conclusion: The ALDH2 rs671 and CYP2E1 rs2031920 polymorphisms are not associated with HCC susceptibility in East Asians.

Keywords: ALDH2, CYP2E1, Hepatocellular carcinoma, Polymorphism

\section{Introduction}

Hepatocellular carcinoma ( $\mathrm{HCC}$ ) is the most common primary liver cancer and is the third most common cause of cancer-related death. In sub-Saharan Africa and some parts of Asia, it is the leading cause of cancer death. HCC most commonly develops in chronic liver disease patients, the etiology of which includes hepatitis $B$ virus (HBV) and hepatitis $\mathrm{C}$ virus (HCV) infection, alcohol, aflatoxin exposure, hemachromatosis, and $\alpha 1$ antitrypsin deficiency [1]. It is likely that HCC arises as a consequence of complex interactions between genetic risk factors and environmental exposures. Candidate gene and genome-wide association studies have started to explore this area, but the role of genetic factors in HCC development remains poorly understood.

\footnotetext{
* Correspondence: kailiu95@yahoo.com

${ }^{2}$ Department of Hepatopancreatobiliary Surgery, The First Hospital, Jilin

University, Changchun, China

Full list of author information is available at the end of the article
}

Aldehyde dehydrogenase 2 (ALDH2) is a mitochondrial enzyme, which is known for its role in alcohol detoxification. It has the highest affinity for acetaldehyde (ACE) and mediates the rate-limiting step of metabolizing ACE to acetic acid. In addition, ALDH2 metabolizes other aldehydes generated during oxidative stress such as 4-hydroxy-2-nonenal (4-HNE), protecting against oxidative stress [2]. In the human $A L D H 2$ gene, there is a G-to-A point mutation at exon 12, resulting in a glutamic acid-to-lysine substitution at residue 487 (rs671, Glu>Lys) of the ALDH2 protein (designated ALDH2*2) [3]. The rs671 polymorphism is found in nearly $35-50 \%$ of East Asian populations but has not been found in Africans or Caucasians [4]. It is associated with a reduction in the ALDH2 enzymatic activity by 70 and $98 \%$ in heterozygotes and homozygotes, respectively [5]. There are multiple association studies assessing the relationship between $A L D H 2$ rs671 and HCC risk in East Asians. The study by Takeshita et al. was the first study to 
evaluate the association of $A L D H 2$ rs671 with HCC susceptibility, finding no association of the $A L D H 2$ genotypes with HCC development [6]. Their results were supported by several other studies including the study by Liu et al. which was based on a large sample size (600 cases and 3221 controls) [7]. However, the study by Sakamoto et al. suggested that $A L D H 2$ rs671 might modify the risk for developing HCC [8]. The discrepancies among these studies may be due to the modest effect of the polymorphism, variation in ethnic background, and different sample sizes these studies used. Because the findings remain controversial, a quantitative analysis is needed to assess the evidence.

Cytochrome p450 2E1 (CYP2E1) is also one of the important alcohol-metabolizing enzymes. It is strongly expressed in the liver but can also be found in extrahepatic organs such as the brain and kidneys [9]. Hepatic CYP2E1 levels can be induced by chronic alcohol consumption. CYP2E1 metabolizes ethanol and numerous chemicals including environmental pollutants and clinical drugs. Its highly uncoupled NADPH oxidase activity generates high levels of reactive oxygen species, leading to hepatic lipid peroxidation, cell stress, and apoptosis [10]. Human CYP2E1 is located on chromosome 10q26.3 and consists of nine exons and eight introns. It is shown that a restriction fragment length polymorphism (rs2031920, Pst I/Rsa) in the 5'-transcriptional region may modify the CYP2E1 enzyme function or mRNA expression levels [11]. Although several studies from East Asia evaluated the possible association of

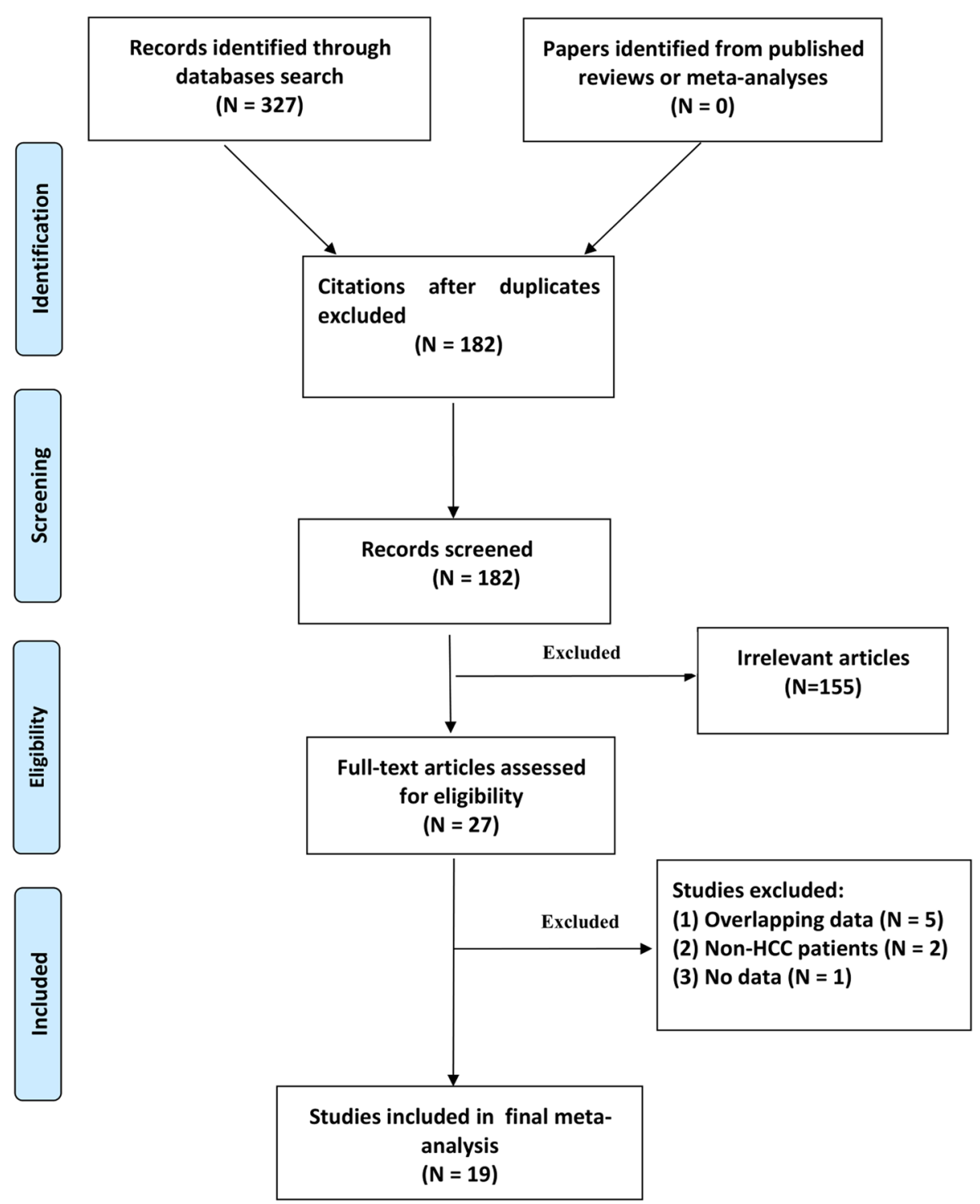

Fig. 1 Flow chart of the study selection 
Table 1 Characteristics of the studies assessing ALDH2 rs671 and HCC susceptibility

\begin{tabular}{|c|c|c|c|c|c|c|c|c|c|c|c|c|c|c|c|}
\hline \multirow[t]{2}{*}{ Author } & \multirow[t]{2}{*}{ Country } & \multirow[t]{2}{*}{ Year } & \multicolumn{4}{|l|}{ Cases } & \multicolumn{4}{|c|}{ Controls } & \multirow[t]{2}{*}{ HWE } & \multirow{2}{*}{$\begin{array}{l}\text { Genotyping } \\
\text { method }\end{array}$} & \multicolumn{2}{|l|}{ Virus infection } & \multirow{2}{*}{$\begin{array}{l}\text { Quality } \\
\text { score }\end{array}$} \\
\hline & & & Total & GG & GA & $\mathrm{AA}$ & Total & GG & $\mathrm{GA}$ & AA & & & Cases & Controls & \\
\hline Takeshita & Japan & 2000 & 102 & 62 & 38 & 2 & 125 & 65 & 49 & 11 & Yes & PCR-RFLP & $\begin{array}{l}8 \text { with } \mathrm{HBsAg}(+) ; 71 \\
\text { with } \mathrm{HCV} \text { antibody }(+)\end{array}$ & $\begin{array}{l}\mathrm{HBsAg}(+), \\
0 \% ; \mathrm{HCV} \\
\text { antibody } \\
(+), 0 \%\end{array}$ & 7 \\
\hline Koide & Japan & 2000 & 84 & 48 & 32 & 4 & 84 & 43 & 33 & 8 & Yes & PCR-RFLP & $\begin{array}{l}\text { HBsAg }(+), 14.5 \% \\
\text { anti-HCV }(+), 81.9 \%\end{array}$ & $\begin{array}{l}\mathrm{HBsAg} \\
(+), 0 \% ; \\
\text { anti-HCV } \\
(+), 7.1 \%\end{array}$ & 6 \\
\hline Yu & China & 2002 & 132 & 67 & 51 & 14 & 134 & 58 & 63 & 13 & Yes & PCR & $\begin{array}{l}\operatorname{HBsAg}(+), 67.9 \% \\
\text { anti-HCV }(+), 5.2 \%\end{array}$ & $\begin{array}{l}\mathrm{HBsAg} \\
(+), 15.7 \% \text {; } \\
\text { anti-HCV } \\
(+), 6.0 \%\end{array}$ & 8 \\
\hline Munaka & Japan & 2003 & 78 & 34 & $\begin{array}{l}44(\mathrm{G} / \\
\mathrm{AA})\end{array}$ & & 138 & 76 & $\begin{array}{l}62(\mathrm{GA} \\
\mathrm{AA})\end{array}$ & & Yes & $P C R$ & $\begin{array}{l}\text { HBsAg }(+), 17.9 \% \\
\text { anti-HCV }(+), 69.2 \%\end{array}$ & $\begin{array}{l}\mathrm{HBsAg} \\
(+), 0.7 \% ; \\
\text { anti-HCV } \\
(+), 7.3 \%\end{array}$ & 8 \\
\hline Kato & Japan & 2003 & 94 & $\begin{array}{l}75(G \\
G A)\end{array}$ & & 19 & 133 & $\begin{array}{l}127(\mathrm{GC} \\
\mathrm{GA})\end{array}$ & $G+$ & 6 & Yes & PCR-RFLP & $\begin{array}{l}\mathrm{HBsAg}(+), \text { not } \\
\text { reported; anti-HCV (+), 100\% }\end{array}$ & $\begin{array}{l}\mathrm{HBsAg} \\
(+), \text { not } \\
\text { reported; } \\
\text { anti-HCV } \\
(+), 0 \%\end{array}$ & 7 \\
\hline Sakamoto & Japan & 2006 & 209 & 117 & 77 & 15 & 275 & 146 & 107 & 22 & Yes & PCR-CTPP & $\begin{array}{l}\text { HBsAg }(+), 9.1 \% ; \\
\text { anti-HCV (+), 85.6\% }\end{array}$ & $\begin{array}{l}\mathrm{HBsAg} \\
(+), 2.2 \% ; \\
\text { anti-HCV } \\
(+), 7.6 \%\end{array}$ & 8 \\
\hline Ding & China & 2008 & 208 & 120 & 64 & 24 & 207 & 133 & 59 & 15 & No & PCR-RFLP & $\begin{array}{l}\text { HBsAg }(+), 72.1 \% \text {; } \\
\text { anti-HCV (+), not reported }\end{array}$ & $\begin{array}{l}\text { HBsAg } \\
(+), 22.2 \% \text {; } \\
\text { anti-HCV } \\
(+), \text { not } \\
\text { reported }\end{array}$ & 8 \\
\hline Tomoda & Japan & 2012 & 264 & 132 & 111 & 21 & 199 & 126 & 60 & 13 & Yes & PCR & $\begin{array}{l}\operatorname{HBsAg}(+), 0 \% \text {; anti- } \\
\operatorname{HCV}(+), 100 \%\end{array}$ & $\begin{array}{l}\text { HBsAg } \\
(+), 0 \% ; \\
\text { anti-HCV } \\
(+), 100 \%\end{array}$ & 6 \\
\hline Abe & Japan & 2015 & 67 & 51 & 16 & 0 & 67 & 62 & 5 & 0 & Yes & PCR-CTPP & $\begin{array}{l}\mathrm{HBsAg}(+), 0 \% \\
\text { anti-HCV }(+), 0 \%\end{array}$ & $\begin{array}{l}\mathrm{HBsAg} \\
(+), 0 \% ; \\
\text { anti-HCV } \\
(+), 0 \%\end{array}$ & 8 \\
\hline Liu & China & 2016 & 600 & 303 & 248 & 49 & 3221 & 1617 & 1354 & 250 & Yes & $P C R$ & $\begin{array}{l}\operatorname{HBsAg}(+), 100 \% ; \\
\text { anti-HCV (+), 0\% }\end{array}$ & $\begin{array}{l}\mathrm{HBsAg} \\
(+), 100 \% ; \\
\text { anti-HCV } \\
(+), 0 \%\end{array}$ & 7 \\
\hline Ye & China & 2018 & 300 & 149 & 121 & 30 & 292 & 152 & 119 & 21 & Yes & PCR-RFLP & $\begin{array}{l}\operatorname{HBsAg}(+), 85.0 \% ; \\
\text { anti-HCV }(+), \\
\text { not reported }\end{array}$ & $\begin{array}{l}\text { HBsAg } \\
(+), 10.3 \% ; \\
\text { anti-HCV } \\
(+), \text { not } \\
\text { reported }\end{array}$ & 8 \\
\hline
\end{tabular}

For $A L D H 2$ rs671, the $\mathrm{G}$ allele is the wild-type allele

CTPP confronting two-pair primers, HWE Hardy-Weinberg equilibrium, NOS Newcastle Ottawa Scale, $P C R$ polymerase chain reaction, RFLP restriction fragment length polymorphism

rs2031920 with HCC susceptibility, the results have been conflicting.

In this study, we aim to perform a meta-analysis to assess the relationship of $A L D H 2$ rs671 and CYP2E1 rs2031920 with HCC susceptibility in East Asian populations.

\section{Methods}

Databases and search strategy

Searches were performed in MEDLINE, PubMed, Scopus, Embase, and China Academic Journals databases from inception to July 8, 2019, by two independent authors (Additional file 1). Searches were built around 
Table 2 Characteristics of the studies analyzing CYP2E1 rs2031920 and HCC susceptibility

\begin{tabular}{|c|c|c|c|c|c|c|c|c|c|c|c|c|c|c|c|}
\hline \multirow[t]{2}{*}{ Author } & \multirow[t]{2}{*}{ Country } & \multirow[t]{2}{*}{ Year } & \multicolumn{4}{|l|}{ Cases } & \multicolumn{4}{|c|}{ Controls } & \multirow[t]{2}{*}{ HWE } & \multirow{2}{*}{$\begin{array}{l}\text { Genotyping } \\
\text { method }\end{array}$} & \multicolumn{2}{|l|}{ Virus infection } & \multirow{2}{*}{$\begin{array}{l}\text { Quality } \\
\text { score }\end{array}$} \\
\hline & & & Total & CC & $\mathrm{CT}$ & $\pi$ & Total & $\mathrm{CC}$ & CT & $\pi$ & & & Cases & Controls & \\
\hline Yu & China & 1995 & 30 & 25 & 5 & 0 & 150 & 95 & 49 & 6 & Yes & PCR-RFLP & $\begin{array}{l}\operatorname{HBsAg}(+), 96.7 \% \text {; anti- } \\
\operatorname{HCV}(+), 16.7 \%\end{array}$ & $\begin{array}{l}\operatorname{HBsAg}(+), 49.3 \% \text {; anti- } \\
\operatorname{HCV}(+), 4.0 \%\end{array}$ & 7 \\
\hline Lee & Korea & 1997 & 108 & 67 & 36 & 5 & 31 & 23 & 6 & 2 & Yes & PCR-RFLP & $\begin{array}{l}\text { HBsAg }(+) \text {, not reported; } \\
\text { anti-HCV }(+) \text {, not } \\
\text { reported }\end{array}$ & $\begin{array}{l}\text { HBsAg }(+) \text {, not reported; } \\
\text { anti-HCV }(+) \text {, not } \\
\text { reported }\end{array}$ & 8 \\
\hline Liu & China & 2000 & 84 & 60 & 22 & 2 & 144 & 80 & 57 & 7 & Yes & PCR-RFLP & $\begin{array}{l}\text { HBsAg }(+) \text {, not reported; } \\
\text { anti-HCV }(+) \text {, not } \\
\text { reported }\end{array}$ & $\begin{array}{l}\text { HBsAg }(+) \text {, not reported; } \\
\text { anti-HCV }(+) \text {, not } \\
\text { reported }\end{array}$ & 7 \\
\hline Yu & China & 2002 & 131 & 83 & 41 & 7 & 134 & 77 & 47 & 10 & Yes & PCR-RFLP & $\begin{array}{l}\operatorname{HBsAg}(+), 67.9 \% \text {; anti- } \\
\operatorname{HCV}(+), 5.2 \%\end{array}$ & $\begin{array}{l}\operatorname{HBsAg}(+), 15.7 \% \text {; anti- } \\
\operatorname{HCV}(+), 6.0 \%\end{array}$ & 8 \\
\hline Kato & Japan & 2003 & 93 & 57 & $\begin{array}{l}36 \\
(\mathrm{CT} \\
T T\end{array}$ & & 115 & 68 & $\begin{array}{l}47 \\
\text { (CT } \\
\text { TT) }\end{array}$ & & Yes & PCR-RFLP & $\begin{array}{l}\text { HBsAg }(+) \text {, not reported; } \\
\text { anti-HCV }(+), 100 \%\end{array}$ & $\begin{array}{l}\text { HBsAg }(+), \text { not reported; } \\
\text { anti-HCV }(+), 0 \%\end{array}$ & 7 \\
\hline Munaka & Japan & 2003 & 77 & 45 & $\begin{array}{l}32 \\
(C T \\
\text { TT) }\end{array}$ & & 138 & 89 & $\begin{array}{l}49 \\
\text { (CT } \\
\text { TT) }\end{array}$ & & Yes & PCR-RFLP & $\begin{array}{l}\operatorname{HBsAg}(+), 17.9 \% \text {; anti- } \\
\operatorname{HCV}(+), 69.2 \%\end{array}$ & $\begin{array}{l}\operatorname{HBsAg}(+), 0.7 \% \text {; anti- } \\
\operatorname{HCV}(+), 7.3 \%\end{array}$ & 8 \\
\hline Meng & China & 2003 & 21 & 1 & 19 & 1 & 50 & 36 & 14 & 0 & Yes & PCR-RFLP & $\begin{array}{l}\text { HBsAg }(+) \text {, not reported; } \\
\text { anti-HCV }(+) \text {, not } \\
\text { reported }\end{array}$ & $\begin{array}{l}\text { HBsAg }(+) \text {, not reported; } \\
\text { anti-HCV }(+) \text {, not } \\
\text { reported }\end{array}$ & 6 \\
\hline Jiang & China & 2004 & 207 & 122 & 76 & 9 & 208 & 131 & 67 & 10 & Yes & PCR-RFLP & $\begin{array}{l}\text { HBsAg }(+) \text {, not reported; } \\
\text { anti-HCV }(+) \text {, not } \\
\text { reported }\end{array}$ & $\begin{array}{l}\text { HBsAg }(+) \text {, not reported; } \\
\text { anti-HCV }(+) \text {, not } \\
\text { reported }\end{array}$ & 6 \\
\hline Wu & China & 2007 & 63 & 43 & 17 & 3 & 86 & 47 & 31 & 8 & Yes & PCR-RFLP & $\begin{array}{l}\text { HBsAg }(+) \text {, not reported; } \\
\text { anti-HCV }(+) \text {, not } \\
\text { reported }\end{array}$ & $\begin{array}{l}\text { HBsAg }(+) \text {, not reported; } \\
\text { anti-HCV }(+) \text {, not } \\
\text { reported }\end{array}$ & 8 \\
\hline Imaizumi & Japan & 2009 & 209 & 127 & 73 & 9 & 256 & 160 & 83 & 13 & Yes & PCR-RFLP & $\begin{array}{l}\operatorname{HBsAg}(+) 9.1 \% \text {; anti- } \\
\operatorname{HCV}(+), 85.6 \%\end{array}$ & $\begin{array}{l}\operatorname{HBsAg}(+), 2.3 \% \text {; anti- } \\
\operatorname{HCV}(+), 7.8 \%\end{array}$ & 6 \\
\hline Di & China & 2013 & 95 & 80 & 15 & 0 & 97 & 84 & 13 & 0 & Yes & PCR-RFLP & $\begin{array}{l}\text { HBsAg }(+) \text {, not reported; } \\
\text { anti-HCV }(+) \text {, not } \\
\text { reported }\end{array}$ & $\begin{array}{l}\text { HBsAg }(+) \text {, not reported; } \\
\text { anti-HCV }(+) \text {, not } \\
\text { reported }\end{array}$ & 8 \\
\hline Ye & China & 2018 & 300 & 203 & 87 & 10 & 292 & 196 & 81 & 15 & Yes & PCR-RFLP & $\begin{array}{l}\text { HBsAg }(+), 85.0 \% \text {; anti- } \\
\text { HCV (+), not reported }\end{array}$ & $\begin{array}{l}\text { HBsAg }(+), 10.3 \% \text {; anti- } \\
\text { HCV (+), not reported }\end{array}$ & 8 \\
\hline
\end{tabular}

For CYP2E1 rs2031920, the C allele is the wild-type allele

HWE Hardy-Weinberg equilibrium, NOS Newcastle Ottawa Scale, PCR-RFLP polymerase chain reaction-restriction fragment length polymorphism

the keywords: "hepatocellular carcinoma," "liver cancer," "aldehyde dehydrogenase 2," "ALDH2," "cytochrome p450 2E1," "CYP2E1," "polymorphism," "genetic variant," "susceptibility," and "development." No restrictions on language or setting were applied. Titles and abstracts were screened against the inclusion and exclusion criteria. Full texts of potentially eligible studies were screened. Reference lists of all included studies and relevant reviews were hand-searched to identify additional eligible studies. The design and report of our meta-analysis followed the Preferred Reporting Items for Systematic Reviews and MetaAnalyses (PRISMA) guidelines [12].

\section{Inclusion and exclusion criteria}

After the removal of duplicates from different databases, the titles and abstracts of the citations were carefully screened. Irrelevant papers were excluded, leaving potential studies for further full-text evaluation. The inclusion and exclusion criteria for the studies were as follows: (1) case-control studies of unrelated individuals using a population or hospitalbased design, (2) evaluation of the relation of $A L D H 2$ and CYP2E1 polymorphisms with susceptibility to $\mathrm{HCC}$, and (3) sufficient data for pooling the odds ratio $(\mathrm{OR})$ and $95 \%$ confidence interval (CI). Exclusion criteria were studies in languages other than English and Chinese, review articles, meeting abstracts, editorials, and animal studies.

\section{Data extraction and quality assessment}

Two authors extracted data from the eligible studies using a standardized template. Data were collected on first author, country of study, year, number of HCC patients and controls, demographics of HCC patients, source of controls, matching criteria, genotyping methods, and counts of genotypes and alleles ( $A L D H 2$ 


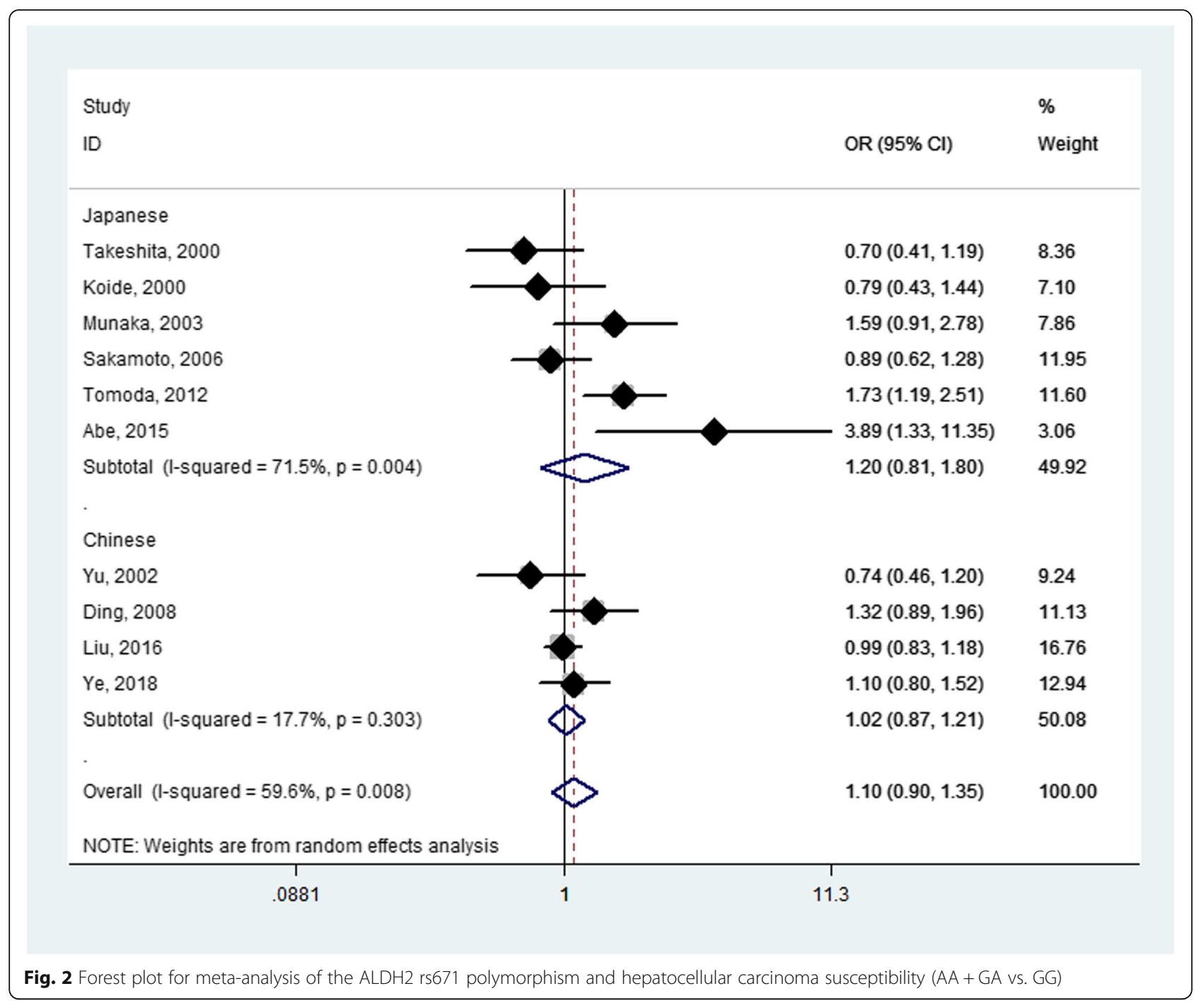

rs671 and CYP2E1 rs2031920). The quality of the included studies was evaluated according to the Newcastle Ottawa Scale (NOS) (www.ohri.ca/programs/clinical_ epidemiology/oxford.asp).

\section{Data analysis}

Since all meta-analyses conducted involved the use of dichotomous data, summary OR with $95 \%$ CIs were presented as the effect measure. The minor allele was considered the at-risk allele. ORs were pooled according to fixed- or random-effects models. The analyses were stratified according to country, Hardy-Weinberg equilibrium status, and source of controls. Heterogeneity was evaluated using the $I^{2}$ statistic, with values higher than $50 \%$ indicating substantial heterogeneity [13]. We performed a sensitivity analysis to ensure that the effect sizes of our meta-analysis were not driven by any one study. We used sensitivity analysis, meta-regression, and Galbraith plot to identify the main contributors to between-study heterogeneity. A cumulative metaanalysis was performed to explore the trend in the effect sizes. Egger's test and funnel plots were applied to assess publication bias. All statistical analyses were conducted using STATA 13.0 (Stata, College Station, TX, USA).

\section{Results}

Summary of included studies

A total of 182 studies were identified after the removal of duplicates from different databases. Twenty-seven articles passed title and abstract screening and underwent full-text review. Nineteen studies met the inclusion criteria and were included in the final analysis. A PRISMA flow chart showing the selection of studies for this meta-analysis is presented in Fig. 1. Eleven studies with 2138 cases and 4875 controls analyzed the $A L D H 2$ rs671 polymorphism 
Table 3 Meta-analysis results for ALDH2 rs671

\begin{tabular}{|c|c|c|c|c|c|c|}
\hline \multirow[t]{2}{*}{ Genotype and subgroup } & \multirow{2}{*}{$\begin{array}{l}\text { Number } \\
\text { of studies }\end{array}$} & \multicolumn{2}{|c|}{ Test of association } & \multicolumn{2}{|c|}{ Test of heterogeneity } & \multirow{2}{*}{$\begin{array}{l}P \text { of } \\
\text { Egger's } \\
\text { test }\end{array}$} \\
\hline & & OR $(95 \% \mathrm{Cl})$ & $Z$ ( $P$ value $)$ & $\bar{P}(\%)$ & $P_{\text {het }}$ & \\
\hline \multicolumn{7}{|l|}{$A A+G A$ vs. GG } \\
\hline Overall & 10 & $1.10(0.90-1.35)$ & 0.369 & 59.6 & 0.008 & \multirow[t]{7}{*}{0.430} \\
\hline HWE (yes) & 9 & $1.08(0.86-1.35)$ & 0.527 & 62.0 & 0.007 & \\
\hline HWE (no) & 1 & $1.32(0.89-1.96)$ & 0.171 & NA & NA & \\
\hline Chinese & 4 & $1.03(0.87-1.21)$ & 0.770 & 17.7 & 0.303 & \\
\hline Japanese & 6 & $1.21(0.81-1.80)$ & 0.362 & 71.5 & 0.004 & \\
\hline Population-based studies & 4 & $0.98(0.80-1.20)$ & 0.859 & 24.1 & 0.267 & \\
\hline Hospital-based studies & 6 & $1.24(0.88-1.75)$ & 0.210 & 68.9 & 0.007 & \\
\hline \multicolumn{7}{|l|}{$A A$ vs. GA + GG } \\
\hline Overall & 9 & $1.19(0.82-1.73)$ & 0.357 & 58.2 & 0.014 & \multirow[t]{7}{*}{0.866} \\
\hline HWE (yes) & 8 & $1.13(0.75-1.71)$ & 0.562 & 61.2 & 0.012 & \\
\hline HWE (no) & 1 & $1.67(0.85-3.28)$ & 0.137 & NA & NA & \\
\hline Chinese & 4 & $1.19(0.93-1.52)$ & 0.165 & 0 & 0.589 & \\
\hline Japanese & 5 & $1.00(0.41-2.42)$ & 1.000 & 76.8 & 0.002 & \\
\hline Population-based studies & 4 & $1.10(0.82-1.49)$ & 0.521 & 8.6 & 0.350 & \\
\hline Hospital-based studies & 5 & $1.26(0.62-2.56)$ & 0.526 & 73.7 & 0.004 & \\
\hline \multicolumn{4}{|l|}{ AA vs. GG } & & & \multirow[t]{8}{*}{0.289} \\
\hline Overall & 8 & $1.08(0.87-1.34)$ & 0.509 & 37.1 & 0.133 & \\
\hline HWE (yes) & 7 & $1.02(0.81-1.28)$ & 0.892 & 33.6 & 0.171 & \\
\hline HWE (no) & 1 & $1.77(0.89-3.54)$ & 0.104 & NA & NA & \\
\hline Chinese & 4 & $1.18(0.92-1.52)$ & 0.191 & 0 & 0.452 & \\
\hline Japanese & 4 & $0.82(0.54-1.26)$ & 0.373 & 58.0 & 0.067 & \\
\hline Population-based studies & 4 & $1.08(0.74-1.57)$ & 0.690 & 24.7 & 0.263 & \\
\hline Hospital-based studies & 4 & $1.00(0.54-1.85)$ & 0.992 & 58.1 & 0.067 & \\
\hline \multicolumn{7}{|l|}{ GA vs. GG } \\
\hline Overall & 9 & $1.06(0.86-1.31)$ & 0.569 & 54.2 & 0.026 & \multirow[t]{7}{*}{0.464} \\
\hline HWE (yes) & 8 & $1.05(0.83-1.32)$ & 0.697 & 58.7 & 0.018 & \\
\hline HWE (no) & 1 & $1.20(0.78-1.85)$ & 0.403 & NA & NA & \\
\hline Chinese & 4 & $0.99(0.85-1.14)$ & 0.833 & 0 & 0.452 & \\
\hline Japanese & 5 & $1.21(0.78-1.89)$ & 0.395 & 70.0 & 0.010 & \\
\hline Population-based studies & 4 & $0.97(0.83-1.13)$ & 0.669 & 0 & 0.452 & \\
\hline Hospital-based studies & 5 & $1.22(0.83-1.78)$ & 0.305 & 69.2 & 0.011 & \\
\hline
\end{tabular}

For $A L D H 2$ rs671, the $\mathrm{G}$ allele is the wild-type allele $\mathrm{Cl}$ confidence interval, NA not applicable, $O R$ odds ratio

[6-8, 14-21], while 12 studies including 1418 cases and 1701 controls assessed the CYP2E1 rs2031920 polymorphism $[11,15-17,21-28]$. The quality score of the eligible studies ranged from 6 to 8 points. The characteristics of the included studies are summarized in Tables 1 and 2.

\section{Quantitative synthesis}

The $A L D H 2$ rs671 polymorphism was evaluated in Chinese and Japanese populations. The overall meta-analysis did not suggest any association between $A L D H 2$ rs671 and HCC susceptibility for AA + GA genotype vs. GG genotype $(\mathrm{OR}=1.10, P=0.369)$, AA genotype vs. $\mathrm{GA}+$ GG genotype $(\mathrm{OR}=1.19, P=0.357)$, AA genotype vs. GG genotype $(\mathrm{OR}=1.08, P=0.509)$, and GA genotype vs. GG genotype $(\mathrm{OR}=1.06, P=0.569 ;$ Fig. 2 and Table 3$)$. The sensitivity analysis revealed that omitting the study by Ding et al. which deviated from HardyWeinberg equilibrium had no effect on the overall 


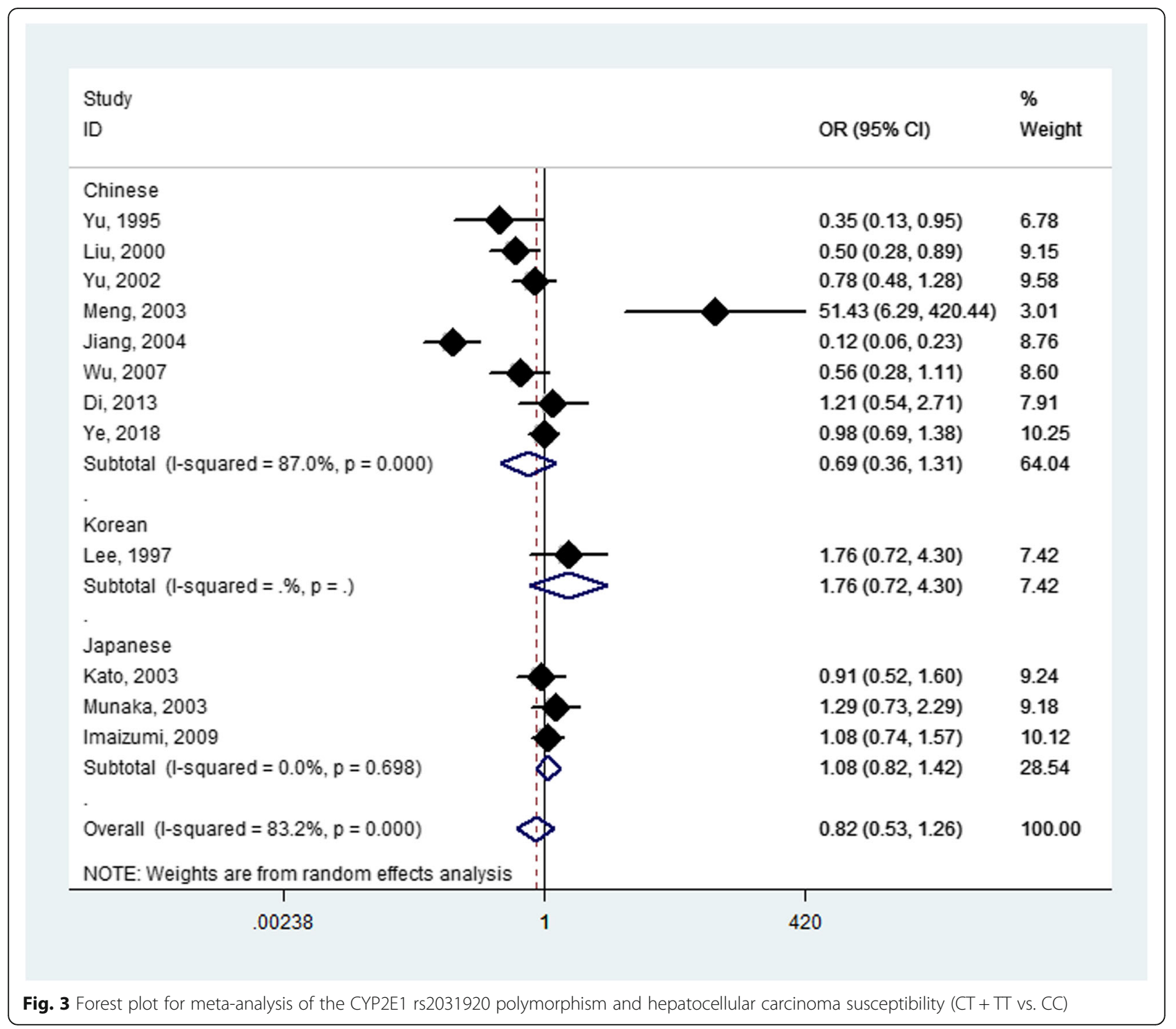

outcome of disease risk [18] (Table 3). Through subgroup analyses by country, no significant associations were found in Chinese or Japanese (Fig. 2 and Table 3). A subgroup analysis by source of controls (populationbased and hospital-based) also did not identify any association (Table 3).

The CYP2E1 rs2031920 polymorphism was assessed in Chinese, Japanese, and Korean populations. There was no association between the polymorphism and HCC susceptibility when combining the results from all eligible studies $(\mathrm{OR}=0.82, P=0.358$ for $\mathrm{TT}+\mathrm{CT}$ vs. $\mathrm{CC}$; $\mathrm{OR}=$ $0.72, P=0.096$ for TT vs. CT $+\mathrm{CC}$; OR $=0.54, P=0.079$ for TT vs. CC; $\mathrm{OR}=0.97, P=0.886$ for CT vs. CC; Fig. 3 and Table 4). All studies conformed to Hardy-Weinberg equilibrium. In the subgroup analysis by country, we did not find any association of CYP2E1 rs2031920 with
HCC susceptibility in Chinese (Fig. 3 and Table 4), Japanese, and Koreans. When the included studies were subgrouped according to the source of controls, the analyses did not show any statistically significant results (Table 4).

\section{Heterogeneity and meta-regression}

Significant heterogeneity was found among the studies evaluating rs671 and rs2031920 (Tables 3 and 4). We performed a meta-regression analysis to explore the potential modifiers contributing to the heterogeneity between the studies that assessed rs671. Year of publication, country, source of controls, and sample size were considered. However, the results showed that these factors were not the sources of heterogeneity $(P=0.101$ for year of publication; $P=0.606$ for country; $P=0.366$ for source of controls; $P=$ 
Table 4 Meta-analysis results for CYP2E1 rs2031920

\begin{tabular}{|c|c|c|c|c|c|c|}
\hline \multirow[t]{2}{*}{ Genotype and subgroup } & \multirow{2}{*}{$\begin{array}{l}\text { Number } \\
\text { of studies }\end{array}$} & \multicolumn{2}{|c|}{ Test of association } & \multicolumn{2}{|c|}{ Test of heterogeneity } & \multirow{2}{*}{$\begin{array}{l}P \text { of } \\
\text { Egger's } \\
\text { test }\end{array}$} \\
\hline & & OR $(95 \% \mathrm{Cl})$ & $Z$ ( $P$ value $)$ & $\bar{P}(\%)$ & $P_{\text {het }}$ & \\
\hline \multicolumn{7}{|l|}{$C T+\Pi T$ vs. $C C$} \\
\hline Overall & 12 & $0.82(0.53-1.26)$ & 0.358 & 83.2 & 0.000 & \multirow[t]{6}{*}{0.843} \\
\hline Chinese & 8 & $0.69(0.37-1.31)$ & 0.259 & 87.0 & 0.000 & \\
\hline Japanese & 3 & $1.08(0.82-1.42)$ & 0.587 & 0 & 0.698 & \\
\hline Korean & 1 & $1.76(0.72-4.30)$ & 0.215 & NA & NA & \\
\hline Population-based studies & 2 & $0.31(0.05-1.98)$ & 0.214 & 95.2 & 0.000 & \\
\hline Hospital-based studies & 10 & $0.97(0.68-1.39)$ & 0.871 & 68.7 & 0.001 & \\
\hline \multicolumn{7}{|l|}{ TT vs. CT + CC } \\
\hline Overall & 9 & $0.72(0.49-1.06)$ & 0.096 & 0 & 0.921 & \multirow[t]{6}{*}{0.714} \\
\hline Chinese & 7 & $0.69(0.44-1.08)$ & 0.107 & 0 & 0.803 & \\
\hline Japanese & 1 & $0.84(0.35-2.01)$ & 0.697 & NA & NA & \\
\hline Korean & 1 & $0.70(0.13-3.82)$ & 0.684 & NA & NA & \\
\hline Population-based studies & 2 & $0.80(0.41-1.57)$ & 0.520 & 0 & 0.717 & \\
\hline Hospital-based studies & 7 & $0.68(0.43-1.10)$ & 0.115 & 0 & 0.818 & \\
\hline \multicolumn{7}{|l|}{ TT vs. CC } \\
\hline Overall & 9 & $0.54(0.27-1.08)$ & 0.079 & 59.0 & 0.012 & \multirow[t]{6}{*}{0.523} \\
\hline Chinese & 7 & $0.47(0.19-1.16)$ & 0.102 & 65.1 & 0.009 & \\
\hline Japanese & 1 & $0.87(0.36-2.11)$ & 0.761 & NA & NA & \\
\hline Korean & 1 & $0.86(0.16-4.73)$ & 0.861 & NA & NA & \\
\hline Population-based studies & 2 & $0.25(0.04-1.67)$ & 0.153 & 84.9 & 0.010 & \\
\hline Hospital-based studies & 7 & $0.70(0.37-1.31)$ & 0.266 & 27.2 & 0.221 & \\
\hline \multicolumn{7}{|l|}{ CT vs. CC } \\
\hline Overall & 9 & $0.97(0.67-1.41)$ & 0.886 & 70.6 & 0.001 & \multirow[t]{6}{*}{0.595} \\
\hline Chinese & 7 & $0.89(0.56-1.42)$ & 0.624 & 75.2 & 0.000 & \\
\hline Japanese & 1 & $1.11(0.75-1.64)$ & 0.607 & NA & NA & \\
\hline Korean & 1 & $2.06(0.77-5.52)$ & 0.151 & NA & NA & \\
\hline Population-based studies & 2 & $1.03(0.69-1.52)$ & 0.899 & 31.4 & 0.227 & \\
\hline Hospital-based studies & 7 & $1.00(0.59-1.68)$ & 0.994 & 76.6 & 0.000 & \\
\hline
\end{tabular}

For CYP2E1 rs2031920, the C allele is the wild-type allele

$\mathrm{Cl}$ confidence interval, NA not applicable, OR odds ratio

0.212 for sample size). The meta-regression results for rs2031920 were similar. Next, we conducted the Galbraith plot and accordingly singled out the studies of Tomoda et al. [19] and Abe et al. [20] as the main sources of heterogeneity for rs671 (graph not shown). Removing these studies decreased heterogeneity $\left(P_{\text {het }}=0.247, I^{2}=22.9 \%\right)$, without significantly influencing the pooled ORs. For rs2031920, removing the studies by Meng et al. [24] and Jiang et al. [25] significantly reduced between-study heterogeneity $\left(P_{\text {het }}=0.096, I^{2}=39.4 \%\right)$ but did not alter the corresponding pooled ORs.

\section{Cumulative meta-analysis and publication bias}

We performed a cumulative meta-analysis to explore the trend in the effect sizes. The calculation showed a lack of association between $A L D H 2$ rs671 and HCC susceptibility (Fig. 4). The results for CYP2E1 rs2031920 were similar (not shown). To evaluate the publication bias, a funnel plot of the logarithm of effect size (logOR) against the precision for each study was generated (Fig. 5). There was no evidence of publication bias using Egger's test (Tables 3 and 4).

\section{Discussion}

HCC is the major cause of cancer mortality in some parts of Asia. The poor prognosis of HCC accentuates the need to develop novel genetic markers and therapeutic approaches. Over the past two decades, the relationship of $A L D H 2$ rs671 and CYP2E1 rs2031920 with HCC susceptibility has been extensively studied among 


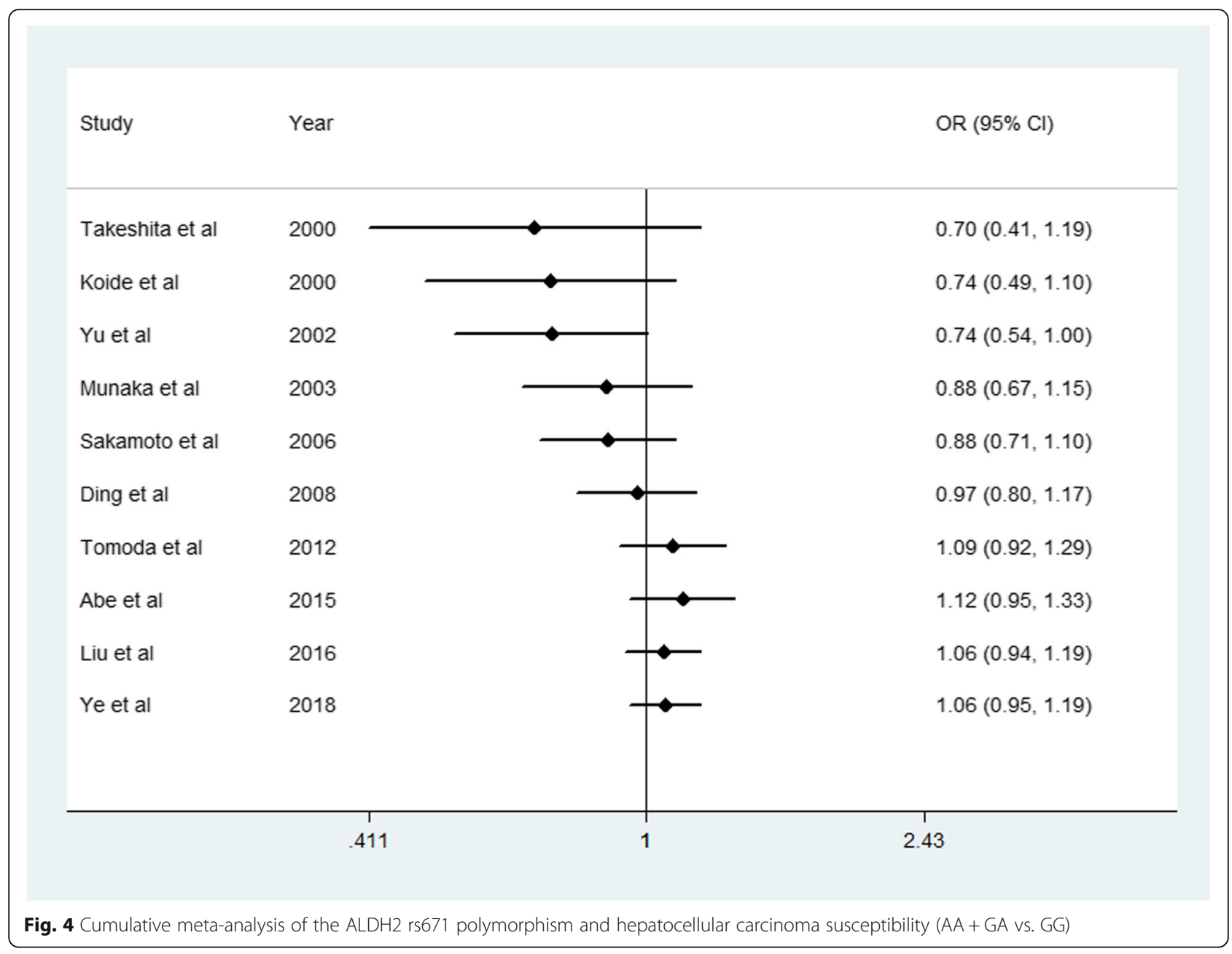

East Asian populations, but there are inconsistencies in the results. In the present study, we reviewed the available literature and performed a meta-analysis regarding these associations. Our results showed no significant effect of $A L D H 2$ rs671 and CYP2E1 rs2031920 on susceptibility to $\mathrm{HCC}$ in East Asians under various genetic models.

This is the largest and most comprehensive metaanalysis on the relationship of $A L D H 2$ rs671 and CYP2E1 rs2031920 with HCC susceptibility in East Asians. The evaluation of $A L D H 2$ rs671 was based on 11 studies with 2138 cases and 4875 controls, whereas 12 studies including 1418 cases and 1701 controls were reviewed for $C Y P 2 E 1$ rs2031920. In addition to the overall meta-analyses, we performed subgroup analyses by country (Chinese, Japanese, and Koreans), HardyWeinberg equilibrium status, and source of controls. Moreover, we conducted a cumulative meta-analysis to see how the evidence had shifted over time. These efforts did not identify any association of $A L D H 2$ rs671 and CYP2E1 rs2031920 with HCC susceptibility. Our findings were supported by most of the included studies.
Among the 11 studies evaluating $A L D H 2$ rs671, 8 reported no association with $\mathrm{HCC}$, including the study by Liu et al. which had the largest sample size (600 cases and 3221 controls) [7]. Concerning CYP2E1 rs2031920, 9 studies did not observe any association. Yu et al. evaluated the association between CYP2E1 rs2031920 and HCC susceptibility in a Chinese population for the first time; they found no association for the CYP2E1 polymorphism [11]. Null association between CYP2E1 rs2031920 and HCC susceptibility was also reported in several Japanese and Korean studies [16, 17, 22, 27]. The findings of the published case-control studies, together with the outcomes from this meta-analysis, suggested that $A L D H 2$ rs671 and $C Y P 2 E 1$ rs2031920 were unlikely to be major contributors to HCC susceptibility in East Asian populations.

There was significant heterogeneity between the included studies. For exploring the potential modifiers contributing to heterogeneity, we conducted a metaregression analysis. We showed that year of publication, country, source of controls, and sample size were not the main contributors to heterogeneity. We did not take 


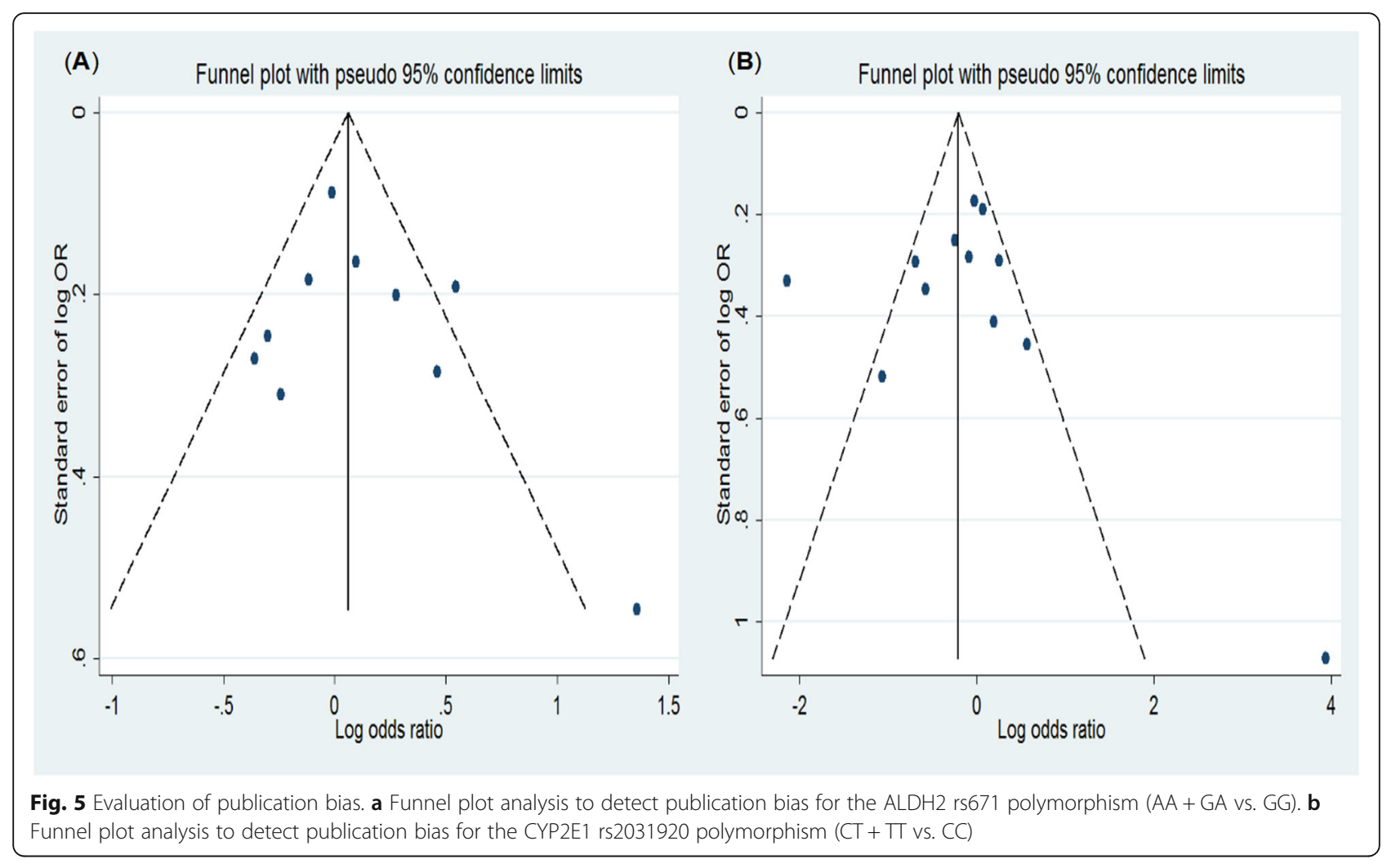

into account other factors such as sex ratio, $\mathrm{HBV} / \mathrm{HCV}$ status, and drinking habits, because not all studies reported the information. It was suggested that metaregression was not always effective in explaining between-study heterogeneity [29]. In addition to metaregression, we conducted the Galbraith plot to explore heterogeneity, finding that the studies of Tomoda et al. [19] and Abe et al. [20] were the sources of heterogeneity for $A L D H 2$ rs671. When these studies were omitted from the overall meta-analysis, the heterogeneity dropped down to $22.9 \%$ ( $P_{\text {het }}=0.247$ ), without significantly affecting the pooled ORs. Concerning CYP2E1 rs2031920, Galbraith's test showed that the studies of Meng et al. [24] and Jiang et al. [25] were the main contributors to heterogeneity; removing them did not alter the overall estimation. Thus, we ensured that the metaanalytic results were robust.

A previous meta-analysis by Zhou et al. reported no association between $A L D H 2$ rs671 and the risk of HCC in East Asians with a total of 1231 cases and 1849 controls [30]. Using a larger sample size (2138 cases and 4875 controls), our study confirmed their findings and provided more information through subgroup analysis and cumulative meta-analysis. In addition, we explored the source of heterogeneity, but Zhou et al. did not perform any analyses for it [30]. For CYP2E1 rs2031920, our results contrasted with those of the meta-analysis by Tian et al. which reported an association between rs2031920 and HCC susceptibility in East Asians [31]. Tian and colleagues' results may be false positive, because they included studies deviating from Hardy-Weinberg equilibrium and pooled overlapping data from the same research group. Two other meta-analyses evaluated the association of rs2031920 with HCC susceptibility using Asian, Caucasian, and Hispanic populations together, but did not find any significant association [32, 33].

Our meta-analysis suggested a lack of association between $A L D H 2$ rs671 and HCC susceptibility, but we could not exclude the possibility that an interaction between ALDH2 rs671 and alcohol drinking may have a role in the development of HCC. Abe et al. found that the profile of alcohol consumption and $A L D H 2$ rs671 had a close relation, and $A L D H 2$ rs671 and the consumptive period affected HCC development in patients with alcoholic liver cirrhosis [20]. In addition, the study by Liu et al. suggested that the association between $A L D H 2$ rs671 and HCC might be significantly mediated by habitual alcohol consumption [7]. However, a principal limitation of these studies was the definition of alcohol drinking, which may cause selection bias. Another limitation was that viral infection was not taken into account. It is known that chronic HBV or HCV infection is common in the Asian continent; adjustment for viral infection may be necessary to clarify whether potential 
interactions between $A L D H 2$ rs671 and alcohol drinking contribute to HCC susceptibility.

Some limitations of our meta-analysis should be considered. First, the eligible studies in our meta-analysis were mainly from Chinese and Japanese. There was only one study from Koreans [22]. Chronic infection with HBV is the predominant risk factor for HCC in China and Korea, while chronic HCV infection is the risk factor for HCC in Japan [34]. A subgroup analysis was performed to evaluate the association of these polymorphisms with HCC in different countries. Second, most of the included studies were hospital based. The controls may not reflect the representative element of the source population. Third, although Egger's test and funnel plots did not suggest publication bias, selection bias might have occurred, because we included only studies written in English and Chinese. Fourth, owing to the insufficient information, we did not perform a subgroup analysis by gender.

In conclusion, the results of our meta-analysis suggest that $A L D H 2$ rs671 and CYP2E1 rs2031920 are not associated with susceptibility to HCC in East Asians. Further, well-designed and population-based studies are needed to evaluate the potential interaction between these polymorphisms and alcohol drinking in HCC susceptibility.

\section{Supplementary information}

Supplementary information accompanies this paper at https://doi.org/10. 1186/s12957-020-1796-0.

\section{Additional file 1: Table S1. Database search strategy.}

\section{Abbreviations}

ACE: Acetaldehyde; ALDH2: Aldehyde dehydrogenase 2; Cl: Confidence interval; CYP2E1: Cytochrome p450 2E1; HBV: Hepatitis B virus; HCC: Hepatocellular carcinoma; HCV: Hepatitis C virus; NOS: Newcastle Ottawa Scale; OR: Odds ratio; PRISMA: Preferred Reporting Items for Systematic Reviews and Meta-Analyses

\section{Acknowledgements}

None.

\begin{abstract}
Authors' contributions
$\mathrm{KL}$ contributed to the conception and design of the study. JC, WP, YC, and $\mathrm{KL}$ searched the aimed studies, extracted the corresponding data, and performed the statistical analysis. JC, WP, YC, LW, JT, and KL contributed to the discussion. JC and $\mathrm{KL}$ wrote the draft of the manuscript. All authors contributed to the manuscript revision and read and approved the submitted version.
\end{abstract}

\section{Funding}

None.

\section{Availability of data and materials}

All data generated or analyzed during this study are included in this published article.

Ethics approval and consent to participate Not applicable.
Consent for publication

Not applicable.

\section{Competing interests}

The authors declare that they have no competing interests.

\section{Author details}

${ }^{1}$ College of Clinical Medicine, Jilin University, Changchun, China.

${ }^{2}$ Department of Hepatopancreatobiliary Surgery, The First Hospital, Jilin

University, Changchun, China.

Received: 27 October 2019 Accepted: 16 January 2020

Published online: 27 January 2020

\section{References}

1. Ngamruengphong S, Patel T. Molecular evolution of genetic susceptibility to hepatocellular carcinoma. Dig Dis Sci. 2014;59(5):986-91.

2. Munukutla S, Pan G, Palaniyandi SS. Aldehyde dehydrogenase (ALDH) 2 in diabetic heart diseases. Adv Exp Med Biol. 2019;1193:155-74.

3. Lee DJ, Lee HM, Kim JH, Park IS, Rho YS. Heavy alcohol drinking downregulates ALDH2 gene expression but heavy smoking up-regulates SOD2 gene expression in head and neck squamous cell carcinoma. World J Surg Oncol. 2017;15(1):163

4. Zhang R, Wang J, Xue M, Xu F, Chen Y. ALDH2---the genetic polymorphism and enzymatic activity regulation: their epidemiologic and clinical implications. Curr Drug Targets. 2017:18(15):1810-6.

5. Ueta CB, Campos JC, Albuquerque RPE, Lima VM, Disatnik MH, Sanchez AB, et al. Cardioprotection induced by a brief exposure to acetaldehyde: role of aldehyde dehydrogenase 2. Cardiovasc Res. 2018;114(7):1006-15.

6. Takeshita T, Yang X, Inoue Y, Sato S, Morimoto K. Relationship between alcohol drinking, $\mathrm{ADH} 2$ and $\mathrm{ALDH} 2$ genotypes, and risk for hepatocellular carcinoma in Japanese. Cancer Lett. 2000;149(1-2):69-76.

7. Liu J, Yang HI, Lee $\mathrm{MH}$, Jen $\mathrm{CL}$, Hu HH, Lu SN, et al. Alcohol drinking mediates the association between polymorphisms of ADH1B and ALDH2 and hepatitis B-related hepatocellular carcinoma. Cancer Epidemiol Biomark Prev. 2016;25(4):693-9.

8. Sakamoto T, Hara M, Higaki Y, Ichiba M, Horita M, Mizuta T, et al. Influence of alcohol consumption and gene polymorphisms of $\mathrm{ADH} 2$ and $\mathrm{ALDH} 2$ on hepatocellular carcinoma in a Japanese population. Int J Cancer. 2006; 118(6):1501-7.

9. Abdulla D, Goralski KB, Renton KW. The regulation of cytochrome P450 2E1 during LPS-induced inflammation in the rat. Toxicol Appl Pharmacol. 2006; 216(1):1-10.

10. Liu T, Wang $\mathrm{P}$, Cong $\mathrm{M}, \mathrm{X}$ U Y, Jia J, You H. The CYP2E1 inhibitor DDC upregulates MMP-1 expression in hepatic stellate cells via an ERK1/2- and Aktdependent mechanism. Biosci Rep. 2013;33(3).

11. Yu MW, Gladek-Yarborough A, Chiamprasert S, Santella RM, Liaw YF, Chen CJ. Cytochrome P450 2E1 and glutathione S-transferase M1 polymorphisms and susceptibility to hepatocellular carcinoma. Gastroenterology. 1995; 109(4):1266-73.

12. Moher D, Liberati A, Tetzlaff J, Altman DG, PRISMA Group. Preferred reporting items for systematic reviews and meta-analyses: the PRISMA statement. PLoS Med. 2009;6(7):e1000097.

13. Higgins JP, Thompson SG, Deeks JJ, Altman DG. Measuring inconsistency in meta-analyses. BMJ. 2003;327(7414):557-60.

14. Koide T, Ohno T, Huang XE, lijima Y, Sugihara K, Mizokami M, et al. HBV/HCV infection, alcohol, tobacco and genetic polymorphisms for hepatocellular carcinoma in Nagoya, Japan. Asian Pac J Cancer Prev. 2000;1(3):237-43.

15. Yu SZ, Huang XE, Koide T, Cheng G, Chen GC, Harada K, et al. Hepatitis B and $C$ viruses infection, lifestyle and genetic polymorphisms as risk factors for hepatocellular carcinoma in Haimen, China. Jpn J Cancer Res. 2002; 93(12):1287-92.

16. Munaka M, Kohshi K, Kawamoto T, Takasawa S, Nagata N, Itoh H, et al. Genetic polymorphisms of tobacco- and alcohol-related metabolizing enzymes and the risk of hepatocellular carcinoma. J Cancer Res Clin Oncol. 2003;129(6):355-60.

17. Kato S, Tajiri T, Matsukura N, Matsuda N, Taniai N, Mamada H, et al. Genetic polymorphisms of aldehyde dehydrogenase 2, cytochrome p450 2E1 for liver cancer risk in HCV antibody-positive japanese patients and the variations of CYP2E1 mRNA expression levels in the liver due to its polymorphism. Scand J Gastroenterol. 2003;38(8):886-93. 
18. Ding J, Li S, Wu J, Gao C, Zhou J, Cao H, et al. Alcohol dehydrogenase-2 and aldehyde dehydrogenase-2 genotypes, alcohol drinking and the risk of primary hepatocellular carcinoma in a Chinese population. Asian Pac J Cancer Prev. 2008:9(1):31-5.

19. Tomoda T, Nouso K, Sakai A, Ouchida M, Kobayashi S, Miyahara K, et al. Genetic risk of hepatocellular carcinoma in patients with hepatitis $C$ virus: a case control study. J Gastroenterol Hepatol. 2012;27(4):797-804.

20. Abe H, Aida Y, Seki N, Sugita T, Tomita Y, Nagano T, et al. Aldehyde dehydrogenase 2 polymorphism for development to hepatocellular carcinoma in East Asian alcoholic liver cirrhosis. J Gastroenterol Hepatol. 2015;30(9):1376-83.

21. Ye X, Wang X, Shang L, Zhu G, Su H, Han C, et al. Genetic variants of ALDH2-rs671 and CYP2E1-rs2031920 contributed to risk of hepatocellular carcinoma susceptibility in a Chinese population. Cancer Manag Res. 2018; 10:1037-50.

22. Lee HS, Yoon JH, Kamimura S, Iwata K, Watanabe H, Kim CY. Lack of association of cytochrome P450 2E1 genetic polymorphisms with the risk of human hepatocellular carcinoma. Int J Cancer. 1997;71(5):737-40.

23. Liu C, Bian J, Shen F, Jiang F. Genetic polymorphism of cytochrome P450 2E1 and susceptibility to hepatocellular carcinoma. Chin J Cancer. 2000; 19(10):862-4.

24. Meng X, Chi B, Gao Y, Sun S. Association between cytochrome P450 2E1 genetic polymorphism and alcoholic liver disease. I Jilin University (Medicine Edition). 2003;29(4):451-3.

25. Jiang A, Wu J, Ding J, Li S, Cao H, SU P, et al. Impact of CYP2E1 Rsa I polymorphism on risk of hepatocellular carcinoma. Chin J Cancer Prev Treat. 2004;11(5):464-6.

26. Wu X, Yang X, Duan W, Wang B, Yang S. The relationship between genetic polymorphism of cytochrome p450 and susceptibility to hepatocellular carcinoma. Acta Academiae Medicinae CPAPF. 2007;16(1):47-8.

27. Imaizumi T, Higaki Y, Hara M, Sakamoto T, Horita M, Mizuta T, et al. Interaction between cytochrome P450 1A2 genetic polymorphism and cigarette smoking on the risk of hepatocellular carcinoma in a Japanese population. Carcinogenesis. 2009;30(10):1729-34.

28. Di J, Zhao J. CYP2El gene polymorphism and susceptibility of hepatocellular carcinoma in Qinghai Tibetan population. J Qinghai Med Coll. 2013;34(2): 97-101.

29. Baker WL, White CM, Cappelleri JC, Kluger J, Coleman Cl, Health Outcomes, Policy, and Economics (HOPE) Collaborative Group. Understanding heterogeneity in meta-analysis: the role of meta-regression. Int J Clin Pract. 2009;63(10):1426-34.

30. Zhou D, Xiao L, Zhang Y, Xian J, Jiang J, Zong W, et al. Genetic polymorphisms of ALDH2 and ADH2 are not associated with risk of hepatocellular carcinoma among East Asians. Tumour Biol. 2012;33(3):841-6.

31. Tian Z, Li YL, Zhao L, Zhang CL. CYP2E1 Rsal/Pstl polymorphism and liver cancer risk among east Asians: a HuGE review and meta-analysis. Asian Pac J Cancer Prev. 2012;13(10):4915-21.

32. Liu C, Wang H, Pan C, Shen J, Liang Y. CYP2E1 Pst//Rsal polymorphism and interaction with alcohol consumption in hepatocellular carcinoma susceptibility: evidence from 1,661 cases and 2,317 controls. Tumour Biol. 2012;33(4):979-84

33. Liu W, Tian F, Dai L, Chai Y. Cytochrome P450 2E1 gene polymorphism and alcohol drinking on the risk of hepatocellular carcinoma: a meta-analysis. Mol Biol Rep. 2014;41(11):7645-50.

34. Zhu RX, Seto WK, Lai CL, Yuen MF. Epidemiology of hepatocellular carcinoma in the Asia-Pacific region. Gut Liver. 2016;10(3):332-9.

\section{Publisher's Note}

Springer Nature remains neutral with regard to jurisdictional claims in published maps and institutional affiliations.

Ready to submit your research? Choose BMC and benefit from:

- fast, convenient online submission

- thorough peer review by experienced researchers in your field

- rapid publication on acceptance

- support for research data, including large and complex data types

- gold Open Access which fosters wider collaboration and increased citations

- maximum visibility for your research: over $100 \mathrm{M}$ website views per year

At BMC, research is always in progress.

Learn more biomedcentral.com/submissions 